\title{
THE CHARACTERISTICS OF THE MOROCCAN DIALECT USED IN TRADITIONAL ORAL TALES
}

\author{
Driss CHERKAOUI*
}

The College of William and Mary

BIBLID [1133-8571] 26 (2019) 18.1-19.

\begin{abstract}
This article explores the cultural and linguistic aspects of Moroccan traditional tales, which are performed in public by storytellers. We examine how the dialect, Moroccan Darija, is used in these performances. Some expressions such as proverbs may be readily understood crossculturally, while others are culturally specific. There are also opening and closing expressions or expressions with religious overtones which may be used so often that they can be qualified as formulae. The article presents examples of various types of repetitions, such as diacope (repeating words separated by other words), epimone (repetition to stress a point) or polyptoton (use of different words based on the same root); examples of synonyms to emphasize a point; use of antonyms; rhymes; changes in tone; use of sarcasm, all of which highlight the poetic richness of Moroccan Darija, an oral language long undervalued by scholars.

Key words: Darija, Moroccan dialect, Oral Stories, Formulae, The Poetic of Narration, Moroccan proverbs.

Resumen: «Las características del árabe marroquí empleado en la tradición oral». Este artículo explora los aspectos culturales y lingüísticos de los cuentos tradicionales marroquíes, que los narradores narran en público. Examinamos cómo se usa el, Darija marroquí, en estas actuaciones. Algunas expresiones, como los proverbios, pueden entenderse fácilmente entre culturas, mientras que otras son culturalmente específicas. También hay expresiones de apertura y cierre o expresiones con connotaciones religiosas que pueden usarse con tanta frecuencia y que pueden calificarse como formas lingüísticas. El artículo presenta ejemplos de varios tipos de repeticiones, como diácope
\end{abstract}

* E-mail: drisscherkaoui1@gmail.com. 
(palabras repetitivas separadas por otras palabras), epítone (repetición para enfatizar un punto) o polyptoton (uso de palabras diferentes basadas en la misma raíz); ejemplos de sinónimos para enfatizar un punto; uso de antónimos; rimas cambios en el tono; uso del sarcasmo. Todo cual resalta la riqueza poética del Darija, una variedad oral subestimada por los estudiosos.

Palabras clave: Darija, Dialecto marroquí, Literatura oral, Fórmulas, Narración poética, Proverbios marroquíes.

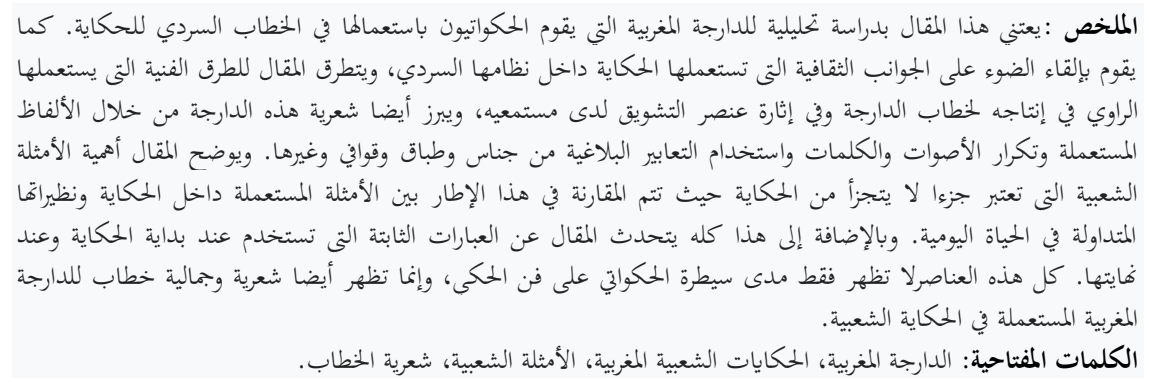

\section{Introduction}

This article explores the use of Moroccan Darija in traditional oral tales, which are still performed today in public spaces in Morocco, such as $\mathrm{Jama}^{\mathrm{c}}$ Lafna in Marrakech or the Place Lahdim in Meknes. They are lively performances and provide engaging distraction for literate and illiterate listeners alike. The storytellers master a wide variety of both subject and sources; they may tell animal stories, religious stories, stories of heroes or chivalry, tales derived from One Thousand and One Nights, the Story of ${ }^{c} A n t a r^{(1)}$, or other ancient sources, or tales arising from their own imaginations. Although the storytellers may mix in some classical Arabic, they primarily use Moroccan Darija, rich in idiomatic expressions, proverbs and rhymes that would be easily understood by the local audience.

To discuss the linguistic tools used by the storytellers, I will begin by discussing the tale's beginning and end, which are much shorter than the central narrative portion, and tend to rely quite heavily on formulaic expressions. Then, I will consider in depth the narrative section.

(1) Cherkaoui 2001. 


\section{Beginning and ending the tale}

Merriam Webster (1982) defines a literary formula as «a conventionalized statement intended to express some fundamental truth or principle especially as a basis for negotiation or action» which is nearly identical to the definition proposed in 1928 by the American scholar Milman Parry, who specialized in ancient Greek epics and is credited with creating the field of oral traditions. Later scholars, such as Majorie Windelberg and D. Gary Miller, in 1980, have argued that this definition is not inclusive enough, and that the concept of formula is more complex than is immediately apparent. To prove the point, they presented the main theories of academics who attempted to define formulae between Parry and themselves, a span of fifty years. Their conclusion was that divergence from a set form does not automatically destroy a formulaic expression, as long as the expression remains part of a pattern of knowledge about the world stored by (and readily available to) the storyteller and his audience $^{(2)}$.

Thus, I use the term formulae here to indicate expressions used in a given context, which may be identical or simply similar to one another, but which will always be widely understood by native speakers of the language in which the formula is used. Many Moroccan tales begin with a formula, and they often end with one as well. Furthermore, we can find formulae embedded in the narrative. These formulae act as signposts to the listener, as everyone knows what they mean or what they imply.

Both opening and closing formulae, when present, usually situate the tale in a larger context than simply the storyteller's personal experience, reinforce its legitimacy and provide the story with added credibility. In some cases, however, the storyteller uses formulae such as hajītek ${ }^{(3)}$ or hajītkum («I am telling you»).

In this case he or she emphasizes their personal credibility to reinforce the story. Similar openings include hajītek wa mā jītek or hajītkum wa mā jìtkum («I

(2) Windelberg \& Miller (1980).

(3) The transliteration system I used is as follow : (alif = '; thä' $=$ th; $h \bar{a} \bar{a}^{\prime}=h$; $k h \bar{a}{ }^{\prime}=k h$; shin $=$ $s h$ and if it carries shedda it's always preceded by al- and thus becomes al-sh; șād $=s$, d dād = $d ; t \bar{a}^{\prime}=t,{ }^{c}$ ayn $={ }^{c} ;$ ghayn $=g h ; q \bar{a} f=q ; w \bar{a} w=w ;$ alif lām $=a l ;$ alif as a long vowel $=\bar{a} ;$ $y \bar{a}$ 'as a long vowel $=\bar{\imath} ; w \bar{a} w$ as a long vowel $=\bar{u})$. 
have told you, I have not come to you»); even though the first expression in Darija is singular and the second plural, the English translation is the same for both. The meaning of this phrase is as obscure in Arabic as it is in English, but the expression is immediately understood by a Moroccan audience as a tale introduction, and not subjected to further scrutiny.

An opening formula or salutation often has the purpose of situating the tale long ago in the past, implying that it contains ancient transmitted wisdom. There are a number of common ones such as gallu («It was said») including variations such as bismillah, gallik... («in the name of God, it was said to you...»). The latter is nearly always followed by the demonstrative pronoun to introduce the first character of the story, as in bismillah, gallak hada wāhad arrājal... or for the feminine hadi wähad lamra... («in the name of God, it was said to you that this man-or this woman...»). Note that wăhad (one) does not change to match the gender in this context. In Darija, when wähad precedes a noun, it is invariable.

The opening kān ya ma kān hetta kān Allah fi kull-mkān wa kān laḥbeq wa as-susān fi hjar an-nabi al-cadnān («it was and it was not, and Allah was everywhere and basil and thyme grew under the Prophet's feet») is the one that most readily translates the common English tale opening «once upon a time.» A variant of this is kān ya makān hetta kān fi-qadīm az-zamān, wāḥed al-malik («it was and it was not in ancient times, there was a king»). Another similar opening is kān hetta kān, kān fi qadim az-zamān («there was until there was, there was in ancient times»).

Some tales also close with formulae, such as hajjaytna mshāt al-wād alwād wa hena bqina $m a^{c}$ a lajwād («our story left river to river and here we remained behind with the generous ones»); 'iwa häda huwwa al-kalām («these are the words that were spoken»); häda ma galu el-jwād wa Allah ${ }^{c} \bar{a} l e m$ («this is what the generous ones said and God knows [all]»); 'iwa Allah yakhlaf wa yajcal al-baraka («May God reward and bless [us all]»). This last formula includes the idea that the storyteller has reached the end of a long story and it is time to stop for now. Not all tales end with a formula. In The Story of the Human Being, the Woodcutter ${ }^{(4)}$ which we will discuss in greater detail when considering narration, the storyteller does not use a closing formula but simply

(4) Cherkaoui (2004). 
repeats a reference early in the story to a human being, using the final sentence of the tale to apply its lessons to human beings in general.

\section{The narrative}

\subsection{Introduction}

Central to the storytellers' performances is the plot and structure of the tale itself, which are embodied in the central narrative section. Typically, the musicality of the taleteller's language is striking, and testifies to his artistry. He may use a mixture of different verbs in various tenses; add illustrative movements to the detailed descriptions of the characters' gestures; or use language and narrative techniques to create suspense, all of which encourage the listeners to enter into the story and identify with the characters' actions rather then being passive observers. The story thus takes on its own life, with a soul, and the characters becomes real to the audience, even if they lived in an imaginary world or in ancient times.

\subsection{Narrative description}

The level of detail used in the narrative and the gradual buildup of the description of a situation, can be seen-and heard!-in the storyteller's description of the situation of the main character, the woodcutter, at the beginning of The Story of the Human Being, the Woodcutter:

Skhan lhāal, al-shamsh sha'clāt, wa huwa yactash. Weld lablād, 'āraf wāhed lbir, 'candu twisa wa ${ }^{c}$ andu twalāt, dāz ldāk lbir, huwa qarrab lbir, bda kayacqud aț-tāsa, whuwa kayasma ${ }^{c}$ lhass fi lbir, wah, wehuwa hat aṭ-țāsa wṭal wa smac lhadra, qāl ahya, shkūn 'elli hna f-lbir, shkūn ntuma, shkun elli hna? hșalna 'iwa 'taqna!

«The weather grew hot, the sun burned like an inferno, and the woodcutter grew thirsty. He was a son of this land, and knew of a well; he had a little bowl and a rope, so he went to the well but as he approached and was preparing to lower the cup into the water, he heard a noise coming from inside the well. He set the cup aside and - eh! - he leaned over the well, where he heard speaking and called out. Who is here, in the well? Who are you? Who is here? [The answer came]. We've been trapped, so save us!».

The storyteller could simply have said that the weather was hot and the woodcutter was thirsty, so he went to the well where voices called out to be saved, but chose instead a wealth of detail presented in poetic language, with accompanying gestures and intonation, like a play in the theatre. For example, 
when he begins the second sentence, his tone becomes sympathetic to the character rather than straight-forward description, and when the woodcutter hears voices, the storyteller's voice changes to express the character's surprise and fear.

In the Darija transcription of the woodcutter above, note the presence of repetitive sounds, such as sh, tw and wah/weh in the following words:

- al-shamsh shaclät and $y a^{c} t a s h$

- twisa (a diminutive form) and twalāt

- wah (an interjection of surprise) and wehuwa as well as 'iwa, an interjection similar to «wah», but implying a result, although sometimes it is used as question-word in the context of a discussion, like the English term «and so?» or «then what?».

Notice, too, the use of the very common expression weld al-blād meaning someone local and the use of bir five times, emphasizing the importance of water in the region.

In the story of the woodcutter, there is also extensive use of alliteration and onomatopoeia. For example, the storyteller uses the word tren! which is not a word but a sound to express a sudden action; he also uses the sound ssett! for the same reason.

In addition to describing the story's setting, the storyteller always takes pains to describe his characters, often through the speech of the characters who may be talking about themselves or another character. For instance, in the story of the woodcutter, the character of the lion gives the woodcutter advice concerning a third character, a man trapped in the well:

Shetti hadāk benādam, sacafni lā țal ${ }^{c} u$ sh. Lmalamih nta ${ }^{c}$ wajhu ${ }^{c}$ alayhum al-shar...benādam mashi wāhad, insān khāyab..tllu dyālu mā candak fih khir.

«Did you see that human being? Take my advice, don't pull him out [of the well]. The features of his face are evil, humans are not all alike, this one is nasty, if you bring him out of the well, nothing good will come of it».

The storyteller could have simply said khallih yemut! («let him die») or khallih yedabbar lrāsu («let him see to himself») rather than the more elaborate version he actually uses. 
The use of the word benädam, from the words banu adam («the sons of Adam»), is interesting in that it means not just an individual person but any human being, and has religious overtones. In this case, it refers to a particular man but in fact it can be used to designate any man or woman, child or adult.

\subsection{The storyteller's use of advice-giving}

Advice is common in traditional Moroccan tales. In the tale of the woodcutter mentioned above, one of the characters, a cobra who has the ability to talk, added to the lion's advice with her own advice against bringing the human out of the well, again using the word benādam: shefti hadāk benādam, yak khūk hadāk men tayna wah̆da, sacafni lā țal'ūsh. («You see that human, this brother of yours, made from the same clay? Take my advice, don't bring him up!»).

Note that rather than saying not to bring that man up ( $m \bar{a} t \operatorname{tal}^{c} \bar{u} s h$ hadāk arrājl) or that fellow (hadāk khayyi) the cobra uses the more evocative phrase yak $k h \bar{u} k$ hadāk men tayna wahda («this brother of yours made from the same clay»), with its overtones of Quranic language ${ }^{(5)}$; and then uses the imperative $s a^{c}$ afni (take my advice) to try to persuade the woodcutter to take her advice. The lion and the mouse in the same story also make similar efforts to persuade the woodcutter, using very similar words.

An example of advice from another story, The Story of the Three Brothers $^{(6)}$, occurs when the father instructs his three sons to divide their inheritance evenly and forbids them to open a certain box when he dies.

In yet another story, a father advises his son not to be friendly with the authorities, not to keep a cow that constantly bellows, not to marry a weeping wife and not to buy a horse born of an old mare: Là tașhab al-makhzan, la taksib al-baghra aț-țawwāha, wa lā takhud lmra an-nuwwāha, wa lā tashri weld

(5) There are multiple Quranic verses referring to the creation of man. See Sürat al-Acrāf, The Heights; Sūrat an-Nisā', The Women; Sürat al-Baqarah, The Cow; Sūrat al-An'ām, The Cattle; Sūrat Fātitr, Originator, among others.

(6) In The Story of the Three Brothers, when the father was dying he advises his three sons to stay together and never opens the wood box in his room. After he passed away the three sons did not get along and each one of them lived his own life and they wasted all the money their dad left them. The young son decided to open the forbidden box. This will lead to all kind of adventures with a magical instruments. 
al- ${ }^{c}$ awda as-shārfa.

Note the rhyme between tawwăha and nuwwāha, and also the association of ideas that both the cow and the wife are noisy; the father is wishing a peaceful life for his son. There is also a close association in sound between tașhab and taksib, as well as the four verbs all starting with the repeated sound of «t», tașhab, taksib, takhud and tashri. The word weld, (son) is used in Darija for the young of animals as well as people, and we see it in expressions such hattā al-făr ${ }^{c}$ andu lawlād (even the rat has children).

The advice in these tales often helps create suspense, particularly if the advice is in the form of an interdiction. The audience waits for what will happen if the advised person does not follow the advice. Vladimir Propp identified the interdiction as the second narrateme, or narrative unit, of 31 commonly found in folk tales; it is one of the first seven narratemes which occur in the introductory part of the story. When the hero ignores the interdiction, as is most often the case, the villain can enter the story either directly or tangentially. Of course, it is important to remember that not all traditional tales start with exactly the same narrative units, nor do all stories manifest all of Propp's units ${ }^{(7)}$.

\subsection{The storyteller's use of repetition to emphasize his point}

A narrative technique commonly found in the oral tales is the use of a series of words with similar meanings to reinforce a single idea. In The Story of the Human Being, the Woodcutter, for example, we find: Drāri kayghawtu, jicanīn, mā candhum mā $y^{c} a t q u$, dāk al-shi haddu qaddu. («His kids were screaming from hunger, they didn't have enough to survive, they barely had enough to manage»). The ideas expressed by the series of words kayghawtu; $j i^{c} a n \bar{\imath} . . .{ }^{c} a t q u$; and $d \bar{a} k$ al-shi haddu qaddu reinforce the description of the extreme poverty and hunger of the woodcutter's children. In addition to repeating and emphasizing the idea of unhappy poverty, the storyteller also repeats the sound $d d u$ in haddu qaddu, which is a common expression meaning barely enough and can be used for other things - such as money-in addition to food or basic necessities. Indeed, the final «u» sound appears four times in this short sentence, and the word $m \bar{a}$ twice, enhancing the musicality of the sentence.

(7) Propp 1968. 
Poverty is a recurring theme in the traditional tales. In the Story of the Woman Who Grew Up in the Forest ${ }^{(8)}$, we find this example of repetition:

Ghatțāt rāsha wellat behāal l-weld, mshāt l'and wāhed shffāj, gālat lu, ah sidi, nakhdam mcak, ghi beshabcat kershi, gal laha sīr aweldi ash 'andak ma takhdam, qālat lu nacjan lak asshfanj wa nțayib lak wa natsakhar lak wa ndir lak kul shi. ${ }^{c}$ tini nakhdam ghi beshab at kershi.

«She covered her head to look like a boy, and went to see a doughnut baker. She said, Oh sir, let me work with you, just enough to fill my belly. He answered, get away from here, boy, you're worthless for work. She said, I can knead the beignets, and cook them for you and do any errands and do everything you need. Give me work just so I can fill my belly».

The girl repeats the idea that she will work just to fill her belly with two similar expressions, nakhdam $m^{c} a k$ («let me work with you») and ${ }^{c}$ tini nakhdam («give me work») and the doughnut maker uses the same verb takhdam. Because of Darija conjugation rules (in this case the same as MSA) all the verbs referring to the girl, end in «at» for a total of six words with this ending. There is also the similarity in sound between $\operatorname{shffaj} j^{(9)}$ («the doughnut maker») and shfanj («the doughnuts themselves»). The expression ash ${ }^{c}$ andak ma takhdam is a common one, used most often in speaking to someone who is lazy. «Ash» is an interrogative, and here it means literally, «what do you have [with which] to work?» but the sense is «you're worthless».

In the story of the woodcutter, the mouse describes the woodcutter's poverty by repeating similar ideas: Nta mjartal wa mrawwan $w m \bar{a}{ }^{c}$ andak tta mātakul («You are dressed in rags, you're a mess, and you have nothing to eat»). The three descriptive terms reinforce the image of the woodcutter's poverty. And when the woodcutter saves the cobra from the well, she also refers to poverty: An-nahār 'elli tekūn hazzi-mazzi, wāqaf, mahtāj, nafdik be ar-rūḥ. («The day when you have real need of me, you are poor and alone, and in desperate need, I will give my life for you»). Hazzi-mazzi is old-fashioned

(8) In this story, a king ordered his baby daughter to be killed but the guards threw her into the forest, where she was raised by animals.

(9) The person who makes shfenj is called shffäj or shefnäj or shfanji. Traditional doughnut shops used to be very popular in Morocco during 1970s and early 1980s. The number of these has declined considerably for multiple reasons, among is the reluctance of young people to take up this kind of employment. 
expression which means that someone has absolutely nothing; wāqaf ${ }^{(10)}$ has the sense of standing alone in poverty and mahtāj means «in desperate need».

The description of poverty is also found in other stories such as in the Moroccan traditional tale The Story of Nür ad-Dinn, when the storyteller describes some men wearing rags and worn sandals labsin drābil wa $n^{c} \bar{a} y i l^{(11)}$. In the same story, one person insults another when he sends him away with the

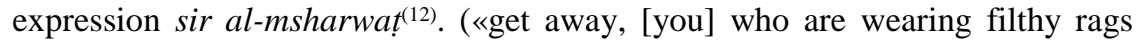
and tatters»). The storyteller describes Nür ad-Dīn's situation by saying ar-ruh bghāt takhraj lih $b i-j \bar{u}^{c}$ («his soul wants to escape from him because of hunger»), indicating that he is starving to death. In these two examples, the type of clothing indicates a very low social class and poverty.

We notice that Moroccan stories contain many references to poverty, and we often find Darija words such as the following, repeated in the same or nearby sentences ${ }^{(13)}$ :

$h \bar{a} z i q$ : (a vulgar expression) meaning absolutely poor, having nothing mlabbik: absolutely poor having nothing mtarraq: absolutely poor having nothing la ryāl lā jüj: [he does not have] even one penny or two

twill: literally, this means «tall» but in certain contexts it means very poor, understood as «he only owns his own height»

darbu yedūr: literally, «hit him, and he'll spin around» meaning he has nothing in his pockets, they are so light he has no firm grounding candu snānu fi fumu: literally, he has his teeth in his mouth, understood as meaning he has only his teeth, owns nothing else, and has no money ${ }^{c}$ andu kabbütu fūq dahru: he has [only] the shirt on his back

(10) Although w-q-f is a root in classical Arabic where the active participle means to stand up while the active participle in Darija carries a connotation of financial need. For example, ana wāqif (I need money), rāna wāqif ${ }^{c}$ Allah, khallașni («you need to pay me what you owe»), wāqif cala bāb Allah («I'm standing at God's gate») in daily parlance means I'm desperately in need of money.

(11) The word $n^{c}$ ayyil in Moroccan Arabic means a peasant's sandal.

(12) The word shrāwat is the plural of sharwita which means piece of cloth with no value.

(13) Similar words referring to poverty are found in standard Arabic and in other literary genres such as novels, plays, poems, and so forth. 


\subsection{The storyteller's use of other common expressions and expressions with} religious overtones

Other common expressions found in The Story of Nūr ad-Dīn include arrjāl mā kattahgar («men should not be humiliated») which two disguised visitors say to $N \bar{u} r a d-D \bar{\imath} n$. In the context of the story, this expression has a meaning close to the English «don't judge a book by its cover» advice against prejudgement or disrespect of someone you do not yet know ${ }^{(14)}$.

In The Story of Mahmoud ibn al-Malik ${ }^{c}$ Uthman $\mathrm{ma}^{c}$ a al-Ghälia bint alManșūr ${ }^{(15)}$, the hero Mahmoud says to his uncle ad-danya ghädia tfūt wa mā khasnāsh ntīqu fiha. («This world is disappearing fast and we should not count on it»). This common expression is used to advise someone to think of preparing for the hereafter by doing, for example, good works in hopes of going to paradise.

An expression from the story of the woodcutter, Jmacti ruq ${ }^{c} a$ wa tban («you've gathered the material and the straw») has the sense of «you've ended up with everything» and it is found in other stories as well, although the expression is not commonly used now in daily life.

An expression that is frequently found in the stories which is also used in daily life is ${ }^{c} u m$ fi bahrak («swim in your sea») and is used to tell someone to solve his own problems, and not to expect help. Likewise, if discussing something very old, the expression $\min ^{c} \bar{a} m$ qarda wa sayyidna Nüh («from the time of Qarda and our Lord Noah») is used ${ }^{(16)}$. Another common expression found in the story of the woodcutter is dak lmalik ${ }^{c}$ andu bentu mqatra min ${ }^{c} i n \bar{h}$ («his daughter is the apple of his eye»). A humorous example of expressions is 'Enta qdāmek yācudu billah, («God save us from your feet») understood to mean whenever you show up there is trouble.

Some common expressions are related to a particular concept, such as

(14) Another example of such widely understood expressions is the expression of condolence, ${ }^{c} a z \bar{a} n a$ wa ${ }^{c} a z \bar{a} k$ wāhid («your solace and mine are one»).

(15) In this story, a king ordered his baby son to be abandoned in the forest because the child's mother died in childbirth and the baby's presence was too strong a reminder to the king of the sadness of losing his wife.The little boy was raised by a lioness, and when he is grown he meets a human queen named al-Ghälia, marries her and becomes a king.

(16) This is the same Noah we find in the Old Testament. 
time. For instance, in The Story of Nür ad-Dīn ${ }^{(17)}$, the storyteller uses a number of expressions referring to time:

cashr ayyām ki al-ghamda («ten days is like closing your eyes»)

kharju fi jawf allayl («they went out into the belly of the night»)

bakri kān... («back in the early days...»)

$s a b^{c}$ ayyām wa sab layāli («seven days and nights»)

al-bārih yāmes walyum al-khämes («yesterday was one thing, today is another»)

fwāhid at-tärikh («in some history») is used by the storyteller when he does not wish to express the exact time.

Notice that these expressions include almost no verbs, only nouns and adjectives. Two of them employ words related to the human body, the word ghamda means to close one's eye for a nap while the word jawf means a person's belly, but here refers to the darkest part of the night.

In addition to ordinary expressions, we find culturally based religious expressions in the stories. Although these contain the name of God, Allah, and are undoubtedly religious in origin, they are understood more as cultural expressions than religious expressions. They are used daily not only by people of different ages and social classes, but more significantly, by non-Muslim Moroccans ${ }^{(18)}$.

Some examples of these expressions with religious overtones found in specific stories include yā subhāna Allah min ghulām lmalik («praise God from being a slave to becoming a king») is found in The Story of Yãqūt and Daw' al

(17) This is a story about a wealthy merchant's son and his adventures as he explores the world.

(18) An example of Moroccan Jews in Israel using one of these expressions can be seen in this video at minute 1:14-1:16 <https://www.youtube.com/watch?v=BQ-9njd9ltk> where we hear a Moroccan Jewish women say Allah $y^{c}$ ammarha $\mathbf{d a} r$. («May God preserve their home»). This is a common expression in Darija where preserve has the sense of providing many children, material wealth and all good things. A Moroccan Jewish man uses the same expression twice in a row in the following clip from minute 1:12-1:15 <https://www.youtube.com/watch?v=FfDDTUCJF-M> [10/25/2019]. 
$M a k \bar{a} n^{(19)}$ and refers to the fact that $Y \bar{a} q \bar{u} t$ started as a slave and became a king. In The Story of Nūr ad-Dìn, we find the expression ysahhal Allah («May God make things easy») used as an expression of encouragement ${ }^{(20)}$. We find variations of this expression such as Rabbi ysahhal in other traditional stories.

Examples of expressions with religions overtones are abundant in traditional stories, and the following examples are only some of these. Yahdar jūd Allah («God's generosity will come») means you should put your faith in God and is used to encourage someone in a difficult financial situation. 'Elli yactaqad, yactaqad fi-Allah («the one who believes should believe in God») is used to encourage someone to be optimistic. 'Ela darti shi hajja dirha lewajh Allah («if you do something good, it should be for God [not in self-interest]»). Allah huwa al-qādir $w$ kun bgha yactina ghādi yactina ( $\mathrm{God}$ is capable of everything and if He wanted us to have something, he would give it to us») is usually said refering to money or material well-being. Wash kāyn 'elli kayacti men ghir Allah («Who besides God is capable of giving?») is an expression used when someone who was counting on another person's help did not receive it. A version of this expression is used by the woodcutter near the beginning of the story when he tries to convince his wife that poverty is their destiny and that she should trust in God: wash kāyan 'elli kayacți min ghir Allah, Allah huwa lqādir rāh kayshuf fina wa ${ }^{c}$ ālam ${ }^{c}$ alina, wa kun bgha yactina rāh ghādi $y a^{c}$ tina.... ( «Is there anyone other than God who gives? God is the one who is able to give, he sees all and knows all, and if God wanted us to have it he would give it to us»).

Another common religious expression found both in the stories and in daily life is Allah ghälib ( God is victorious») which is usually used to or by a person who has not been successful in what he or she set out to do, meaning they did my best but it couldn't match God's greatness. Wāsh naqsad insān wenkhalli al-khāliq? («Should I address a human and not the Creator?») shows the common Moroccan belief that a request should be made directly to God and

(19) The Story of Yāqūt is a long one and includes the following main points: Yāqūt's encounter with the wild knight az-Zettam; his encounter with a djinn who destroyed a bridge; his marriage to the girl he saved, Daw' al Makān; and how he became a king.

(20) In daily life, this expression is usually reversed to Allah ysahhal and almost always used these days to reply to a beggar when one does not wish to give him or her money. 
not to a fellow human, whom you cannot count on. Allah 'elli kaykâfi ( «God is the one who rewards or punishes [you/people]»). A final example of the multitude of religious expressions is swearing, a quite common cultural phenomenon, which often takes the form of beginning a sentence with Wa-Allah («By God»).

Sometimes the storyteller changes register, and suddenly switches from Darija to classical Arabic, using religious expressions. This may be a reflexion of an unconscious acknowledgment of the importance of Islam and the Quran.

However, this is not the only time we can see register shifts, as the technique is also employed to lend gravity to something the storyteller wants to emphasize, and he does so by calling on more formal language ${ }^{(21)}$.

\subsection{The storyteller's use of diminutives}

Classical Arabic grammar includes a diminutive form to refer to small people or things, either to emphasize their cuteness or dearness or to insult or humiliate them. Moroccan Darija exhibits the same feature, although pronunciation of the diminutive form does not follow the classical Arabic pattern of $f u^{c} a y l$

The diminutive form is commonly used in daily life in Morocco but can express different ideas. It may be affectionate, as when a family member addresses a girl named Khadija with the diminutive Dwija or Khdidij or addresses one named Fatima as Fittima. On the other hand, the form may be insulting or pejorative, such as using the word hraymi rather than hrämi (devilish) to belittle someone who is not honest. The diminutive can also be neutral, as in the use of wliyyad instead of «weld» when talking about someone's son. We find extensive use of the diminutive form in traditional stories; examples include khbiza (little bread), khdira (tiny amount of vegetables), zwitnāt (tiny amount of olives), hzima (tiny bundle of sticks), djiyja (very small chicken).

In the story of the woodcutter, the storyteller uses 6 diminutives in his

(21) In The Story of Yāqūt, we find the use of classical Arabic for both religious expressions and to lend gravity to the advice the storyteller is giving his audience, for example where he says 'Ittaqi Allāha tarā ${ }^{c}$ ajabā («Believe in God and you will see [surprises] miracles»); or Khaf min Allāhi takhāfuka al-khalā’iq («Fear God and all beings will fear you»). 
opening sentences to underline the poverty of the woodcutter and his wife. One of these is the wife's comment dāba 'ana nfisa whașni djiyja (I just gave birth and now I need a little chicken); the diminutive form for chicken shows that she is requesting the bare minimum under the circumstances. In this story, the diminutive is frequently used to describe the situation of the person, particularly the financial aspect. The words used in the description of the woodcutter and his wife include hzima instead of hazma,» to indicate a small bunch of faggots for the fire; $l a^{c}$ widat instead of $l a^{c} w \bar{a} d$ to indicate tiny sticks rather than larger sticks used for kindling; zwitnāt instead of zitūn to indicate that even the woodcutter's olives are tiny (implying hunger). In another part of the story of the woodcutter, the storyteller uses the word khwibya, little pot that was full of gold.

\subsection{The storyteller's use of proverbs}

Proverbs express the values of a specific culture, including the beliefs, principals, ways of thinking, philosophy of life, and important themes in that culture. Proverbs in the Moroccan Darija can be classified based on their themes, such as family, justice, trust, greed, cleverness, or charity, among others. It can be challenging to translate the soul of a proverb, as a literal translation may not convey the cultural connotation, and in some cases the literal translation makes no sense at all; however, some proverbs translate easily from one language to another. The Moroccan proverb 'elli dār al-khir yelqāh («do unto others what you want them to do to you») is equivalent to the «golden rule» in English, whereas an English speaker does not so easily understand an expression like lgemla dyālek sakhnāt («your flea has gotten hot»). In English, the equivalent would be «you are looking for trouble». This proverb is found in The Story of the Human Being, the Woodcutter, when the woodcutter's wife is criticizing one of her husband's decisions.

The story of the woodcutter uses proverbs to elucidate important points and to emphasize the lessons that can be taken from those points. All the proverbs occur in the central magical part of this story, and generally appear at turning points. The proverbs in the tale are constantly heard in Morocco in the course of daily activities, but not in the mouths of mice or lions, as they are heard in the story. The proverbs in the tale are not limited to specific characters. The cobra, the mouse, the man in the well, the king and the king's guard each give one; the woodcutter's wife gives two and the woodcutter himself three. Characters of every social class in the story use proverbs. The king and his 
guard (1 proverb each) represent the upper classes; the poorer classes are represented by the woodcutter and his wife (with a total of five proverbs) and the totally dependent animals and man in the well, begging for help, are attributed a total of three proverbs. This distribution mirrors the social universality of proverbs in the culture. Although the poorer classes use them more often, all Moroccan social classes use proverbs.

In addition, the proverbs call attention to key moments in the story, and with their familiar language and accepted truths, anchor those moments in the realm of the possible, within the listener's perception of reality. For example, the cobra uses a proverb to convince the woodcutter to bring the animals up out of the well. The man in the well also uses a proverb to persuade the woodcutter to bring him up. A proverb signals the important moment when the woodcutter decides to call upon the animals for help and there are two proverbs in quick succession when he contacts the mouse. There is another burst of four proverbs in a row at the critical point in the story when the woodcutter is just about to be arrested for having acquired the king's gold. Finally, there is a proverb just before the woodcutter calls upon the cobra to help him get out of jail, a decision that will not only save his life but also better his social status.

Proverbs in other traditional Moroccan stories also sometimes come from animal characters; they are not restricted to human characters ${ }^{(22)}$. The storytellers use many proverbs in their performances. In "The story of The Turtle who Laughs ${ }^{(23)} 》$ the proverb hak 'abūh rajlih jabūh («here is his father, his legs brought him») means the man received what he deserved because he should have minded his own business and not interfered.

In terms of linguistics and syntax, some proverbs are as short as two words

(22) A particularly striking example of this is in «The Story of the Turtle who Laughs.» See the following footnote for a summary of this story.

(23) A man saw a turtle singing and laughing near the river. The man reported this to the king, who was curious to see such a turtle. He was skeptical and asked the man if it was really true; the man replied «if this not true you can take my head off» and so the king invited the turtle to his court. There, the turtle remained silent, even though the king brought musicians and dancers to make him sing and laugh. The king ordered the man's death. As soon as the guards beheaded the man, the turtle laughed and danced. The king, dumbfounded, asked the turtle why he did not do this before, and the turtle replied with the proverb: hak 'abüh rajlih jabūh (a man should never interfere with what is not his business). 
and others are much longer. In The Story of Yāqūt, for example, the storyteller uses the proverb lmida midat Allah, walli ța ${ }^{c}$ mu Allah kayatețam («the food table is from God and the ones whom God feeds will eat»). This proverb is quite long, with repetitions of words, Allah appears twice as does the word for table mida and midat as well as two forms of the verb referring to eating $t a^{c} m u$ and kayatet $t^{c} a m$. Furthermore, the word mida recalls the Quranic verse al-Má'ida (The Table). 'Elli ma jāl $m \bar{a}^{c}$ araf bihaq ar-rijāl («if you do not travel you do not know different kind of people») means that those who have not traveled do not know the value of men and is used when someone narrates a trip, focusing on the importance of the people he met during the trip.

Use of two word proverbs is also common in Moroccan stories as well as daily life. People still routinely use proverbs such as «zwāq yețir» (beauty will vanish); 'ellakhar mbakhar («the last one is lucky»); kri tbāt («rent and you will sleep») means everything has a cost, even a place to sleep; mulāha rabbi («all is in God's hand») is said when a person is about to do something difficult, crazy or stupid. Another proverb rebha walla dabha, («either you win or you die») pertains to a task that is hard, and the message is a person must put in hard work and either they will win or lose.

One famous proverb deeply rooted in Moroccan culture is $S \bar{u} q$ nsa sūq matyār āddakhallu radd bālak («women's business is rough; he who mettles with it should beware»). This is one of the proverbs still in use today that come from the poems of Sidi Abderrahmane al-Majdoub ${ }^{(24)}$ and is used in many stories, particularly the ones in which women play a major role. However, some of the old proverbs used in traditional stories have fallen out of daily use and the current generation is not familiar with them. An example of a proverb still in current use but only among older people is wakha nmadghak mā nsartakch («even if I chew you up, I will not swallow you»). This is used when someone wants to convey the idea that they will stand by another person even if the relationship is not perfect.

Adding proverbs to the storyline strengthens the tale and tends to reinforce its legitimacy. By recognizing so many accepted truths, its own lesson benefits

(24) Sidi Abderrahmane al-Majdoub (1506-1568), was a Moroccan poet, and Sufi mystic. His poems were the source of many proverbs such as «think before you speak». He lived much of his life in Meknes and his tomb is there. 
by association because it is presented as a truth as well. The proverbs also serve to connect tales of magic to the reality of daily life.

\section{Conclusion}

The non-exhaustive examples given in this article makes it clear that the storyteller's Darija is used with art and finesse, poetry and subtlety. Besides the examples discussed here, the stories are rich in rhymes, alliteration, metaphors, and similes, not to mention the rhythm introduced by the intonations of the storyteller's voice, which must also be considered part of language and one of the techniques of oral transmission of these rich traditional tales.

\section{BIBLIOGRAPHY}

ABU-SSAYDEH, Abdul-Fattah. 2004. «Translation of English Proverbs into Arabic». Babel 50, 2, pp. 114-131.

CHERKAOUI, Driss. 2004. The Story of the Human Being, the Woodcutter: the Anatomy of a Traditional Moroccan Oral Tale. The Journal of North African Studies 9, 1, pp. 78-103.

CHERKAOUI, Driss. 2001. Le Roman de Antar : une perspective littéraire et historique. Paris, Présence africaine.

COLIN, Georges. 1957. Recueil de textes en arabe marocain, I : contes et anecdotes. Paris, Maisonneuve.

CONNELLY, Bridget Ann. 1986. Arab Folk Epic and Identity. Berkeley and Los Angeles, University of California Press.

DUNDES, Alan. 1983. Cinderella: a Casebook. New York. Heidegger, Wildman Press.

HEIDEGGER, Martin. 1976. Acheminement vers la parole. Paris, Gallimard, Paris.

IBN CALI, al-Husayn. 1999. Qisas wa 'Amthāl min al-Maghreb. al-Jadida Casablanca, Matbacat al-Najāh.

KOSSMANN, Maarten. 2000. A Study of Eastern Moroccan Fairy Tales. Helsinki, Suomalainen Tiedeakatemia Academia Scientiarum Fennica.

LAOUST, Emile. 1949. Contes Berbères du Maroc. 2 vols. Paris, Larose. 
MUHAWI, Ibrahim \& KANANA, Sharif, 1989. Speak Bird, Speak Again, Palestinian Arab Folktales. Berkeley, University of California Press.

PROPP, Vladimir. $1968^{2}$. Morphology of the Folktale. Trans. Laurence Scott. Austin, University of Texas Press.

WINDELBERG, Marjorie \& MILLER, Gary. 1980. «How (Not) to Define the Epic Formula». Olifant 8, 1, pp. 29-50.

<https://scholarworks.iu.edu/journals/index.php/olifant/article/download/1 9120/25241/0> [10/25/2019]. 